\section{REFERENCES}

1. Benson JS. FDA Safety Alert: Needlestick and other risks from hypodermic needles on secondary IV administration setspiggyback and intermittent IV. Rockville, MD: Food and Drug Administration; 1992. Letter to all US physicians.

2. Danzig LE, Short LJ, Collins K, Mahoney M, Sepe S, Bland L, et al. Bloodstream infections associated with a needleless intravenous infusion system in patients receiving home infusion therapy. JAMA 1995;273:1862-1864.

3. Kellerman S, Shay DK, Howard J, Goes S, Feusner J, Rosenberg $\mathrm{J}$, et al. Bloodstream infections in home infusion patients: the influence of race and needleless intravascular access devices. $J$ Pediatr 1996;129:711-717.

4. Do A, Ray B, Barnett B, Pham M, Ball L, Hendricks K, et al. Evaluation of the role of needleless devices in bloodstream infections in home infusion therapy. Presented at the 36th Interscience
Conference on Antimicrobial Agents and Chemotherapy; September 17, 1996; New Orleans, LA.

5. McDonald LC, Banerjee S, Jarvis W. Central venous catheterassociated bloodstream infections in intensive-care unit patients associated with needleless access devices. Infect Control Hosp Epidemiol 1997;18:P24. Abstract 28.

6. Cookson ST, Ihrig M, O'Mara EM, Hartstein AI, Jarvis WR. Use of an estimation method to derive an appropriate denominator to calculate central venous catheter-associated bloodstream infection rates. Infect Control Hosp Epidemiol 1998;19:000-000.

7. Ihrig M, Cookson ST, Campbell K, Hartstein AI, Jarvis WR. Evaluation of the acceptability of a needleless vascular access system by nurses. Am J infect Control 1997;25:434-438.

8. Kleinbaum DG, Kupper LL, Morganstern H. Epidemiologic Research: Principles and Quantitative Methods. New York, NY: Van Nostrand Reinhold; 1982.

\title{
Chlamydia and Risk of Coronary Artery Disease
}

\section{Gina Pugliese, RN, MS Martin S. Favero, PhD}

The presence of a common respiratory pathogen, Chlamydia pneumoniae, poses a fourfold risk of secondary cardiac complications following myocardial infarction. Researchers from the St George's Hospital Medical School, London, reported data that suggests that this excess risk can be reduced with a 3-day course of azithromycin.

The researchers studied 213 male postmyocardial infarction (MI) survivors in a randomized placebocontrolled trial of azithromycin. They found that patients with the highest anti- $C$ pneumoniae (Cp) antibody titers had four times the risk of postMI cardiac events such as myocardial infarction, coronary artery bypass grafting, angioplasty, and angina in the 18 months following their MI compared with similar patients who had no detectable $\mathrm{Cp}$ antibodies. $\mathrm{Cp}$ positive patients who received azithromycin had a risk of cardiac events equivalent to that of patients with no detectable $\mathrm{Cp}$ antibodies, regardless of possible confounders, such as smoking, diabetes, and aspirin therapy.

The findings of this study may explain, in part, the huge (up to 60\%) variation in coronary heart disease prevalence and severity. The authors believe that $\mathrm{Cp}$ may be carried in the arteries by the macrophages and promote atherosclerosis either by setting up chronic inflammation or by triggering production of prothrombotic factors such as tissue factor.

An increase in anti-Cp antibody titers may be a risk factor for further adverse cardiovascular events in postMI patients. Taking a short course of azithromycin (500 $\mathrm{mg}$ per day for 3 to 6 days) may lower this risk, possibly by acting against the $C$ pneumoniae. The authors concluded that the study has important implications for prevention of both secondary and primary coronary events, particularly given the safety and low cost of azithromycin.

FROM: Gupta S, Leatham EW, Carrington D, Mendall MA, Kaski JC, Camm AJ. Elevated Chlamydia pneumonia antibodies, cardiovascular events, and azithromycin in male survivors of myocardial infarction. Circulation 1997;96:404-407. 